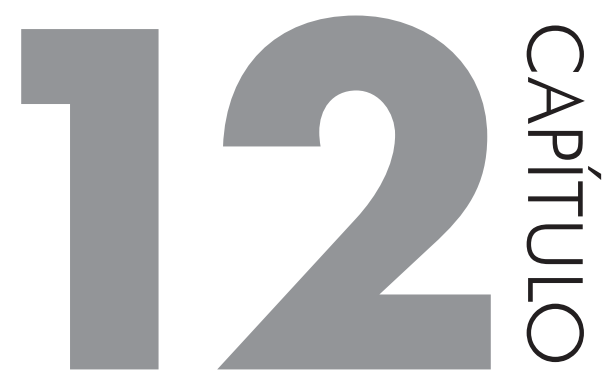

\title{
TUTORIA EAD NO CURSO DE CIÊNCIAS CONTÁBEIS
}

\section{REGIANE CUNHA DA SILVA}

\section{APRESENTAÇÃO DO TUTOR}

Meu nome é Regiane Cunha, sou Mestra em Ciências Contábeis pela UFPE, Empregada Pública Federal, possuo 21 anos de experiência em Gestão Empresarial e atuo há 02 anos como Tutora EaD do Curso de Ciências Contábeis - UFPE.

\section{SÍNTESE DO PERCURSO}

Tive a oportunidade de mediar as disciplinas de Metodologia Científica Aplicada às Ciências Contábeis, Ética e Normas da Profissão Contábil, Contabilidade Aplicada ao Terceiro Setor, Estágio Supervisionado e Trabalho de Conclusão de Curso. Também pude contribuir com os conteúdos das disciplinas de Metodologia Científica Aplicada às Ciências Contábeis, Normas e Ética da Profissão Contábil e, ainda, com a disciplina de Contabilidade, elaborando o material didático (apostila), sempre sob a orientação da Profa. Cacilda Andrade.

\section{FATO MARCANTE}

Um fato marcante foi a experiência de poder conhecer alguns alunos e observar que eles ainda não compreendem que a oportunidade do ensino à distância 
lhes permite vencer muitas barreiras, como por exemplo: a da distância, dos custos de deslocamento e da flexibilidade de horários.

Também foi possível saber, através do depoimento de alguns, que ao ingressar nessa modalidade de ensino, julgavam ser mais fácil, e, no entanto, só com o decorrer do curso é que eles vieram a perceber que precisavam absorver uma postura mais ativa, no sentido de se dedicarem mais às pesquisas e à construção do seu próprio conhecimento.

E que o fato do curso não ser presencial, não significa que o professor está ausente, que não consegue monitorar as ações dos alunos e avaliá-los.

\section{MÉTODO POTENTE UTILIZADO NO PROCESSO DE ENSINO-APRENDIZAGEM}

Considero que além de se preocupar em subsidiar os alunos na compreensão dos conteúdos, e também no incentivo à pesquisa, um dos aspectos fundamentais consiste em conduzir o aluno a tomar posse de sua própria autonomia, motivando-o a enfrentar os desafios diários do aprendizado à distância. Nessa perspectiva, provocando-lhe a curiosidade e direcionando-o para a pesquisa.

\section{LIMITAÇÕES}

As limitações, posso dizer, podem estar muito mais dentro de cada um de nós, a partir do momento em que nos posicionamos com resistência a tudo o que possa ser desafiador. Eu diria então que um dos maiores desafios é ajudar o aluno, nessa conquista: a de sua própria responsabilidade com o seu aprendizado, ajudando-o a estabelecer os seus objetivos, e a desenvolver a sua autodisciplina.

\section{PERSPECTIVA DA TUTORIA COMO PROJETO EDUCACIONAL}

A perspectiva da formação como um processo contínuo e a crescente demanda pela socialização e acesso à educação, inseridas em um contexto em que o indivíduo se encontra cada vez mais absorvido por diversas demandas que o limitam, em termos de horários e localização, são aspectos que contribuem para o fortalecimento da expansão do Ensino à Distância (EaD).

A EaD, por ser uma modalidade de ensino que impulsiona o aluno na construção do seu conhecimento, com relativa autonomia, cria uma "zona" em que o Tutor se insira, com um papel fundamental, que visa guiar o aprendiz nessa construção, afim de que não se dispersem pelo caminho.

\section{AGRADECIMENTOS}

Agradeço à Profa. Cacilda Andrade, minha mentora nesta caminhada, ao Departamento de Ciências Contábeis e à Universidade Federal de Pernambuco, a oportunidade da experiência, construção, crescimento e compartilhamento. 